\title{
Measurement Analysis and Evaluation of Desiccant Air Handling Units with Various Heat Source
}

\author{
Taro Sasamoto ${ }^{1, *}$, Makiko Ukai $^{2}$ \\ ${ }^{1}$ Tokyo Gas CO., Ltd., Tokyo, Japan \\ ${ }^{2}$ Graduate School of Environmental Studies, Nagoya University, Nagoya, Japan
}

\begin{abstract}
In hot and humid summer as in Japan, dehumidification is important process for air conditioning. Desiccant air handling unit is one of the major system for dehumidification in which absorbent or sorbent absorbs moisture in the air and hot heat source is required in order to regenerate them. Desiccant air handling unit is becoming common system, however there is little information about actual operation results and evaluation based on the measurement results. This study provides actual data set and benchmarks which are useful for designing desiccant air handling unit and to evaluate energy performance of various desiccant air handling systems. Measurement results show that coefficient of performance of desiccant air handling unit itself is around 0.7 in summer with polymer sorbent. In addition, the coefficient of performance of desiccant air handling system is defined and the value depends on the coefficient of performance of heat source and the distribution between chilled water and hot water.
\end{abstract}

\section{Introduction}

In hot and humid summer as in Japan, dehumidification is important process for buildings in terms of air quality and thermal comfort. Mechanical dehumidification is commonly used to reduce moisture content of the air flow. Most of the dehumidification process is conducted by reducing the air temperature to lower than its dew point, which is so called condensation dehumidification. Alternatively, the desiccant air handling unit can reduce moisture of the air by adsorption phenomena of substances including silica gel or polymer sorbent. These are required to be regenerated periodically. For regeneration, waste heat from combined heat and power (hereafter, CHP) or heat pumps, and hot water from solar thermal system is typically used. Desiccant air handling unit (hereafter, DAHU) is one of the key technology for higher energy performance, however there is little information about actual operation results and evaluation based on the measurement results.

The purpose of this study is to provide actual data set and benchmarks which are useful for designing desiccant air handling unit and to evaluate energy performance of various desiccant air handling system (hereafter, DAHS) including heat sources. Two different DAHS in Tokyo and Kanagawa are selected for this study.

\section{System specifications \\ configuration}

and

\subsection{System 1}

\footnotetext{
Corresponding author: t-sas@tokyo-gas.co.jp
}

Fig. 1 shows the system 1 including DAHU, gas heat pump (hereafter, GHP), CHP, solar thermal system and absorption chiller.

The DAHU of system 1 is composed of precooling coil, dehumidification wheel, regenerating coil, sensible heat exchanger and after-cooling coil. Chilled water from GHP around $8^{\circ} \mathrm{C}$ is supplied to pre- and after- cooling coil. Hot water around $70^{\circ} \mathrm{C}$ from GHP's waste heat is supplied to regenerating coil. When the hot water from GHP is not enough hot, hot water from CHP and solar thermal system is used through heat exchanger for raising the temperature of hot water from GHP. Hot water from CHP and solar thermal system is then supplied to absorption chiller and tank for domestic hot water. Hot water from CHP and solar thermal system is used as cascade system.

Table 1 shows the specification of the system 1 . The target room condition is $27^{\circ} \mathrm{C}$ and $45 \%$. Supply air volume is decided by $\mathrm{CO}_{2}$ condensation of each room. Return air volume is determined by the supply air volume. Supply dew point is determined by the return air dew point.

\subsection{System 2}

Fig. 2 shows the system 2 including DAHU, air handling unit, radiant panel, absorption chiller, CHP, and solar thermal system. The DAHU of system 2 is composed of pre-cooling coil, dehumidification wheel, regenerating coil, sensible heat exchanger and after-cooling coil. Chilled water from absorption chiller is firstly supplied to air handling unit (AHU), and then supplied to pre- and after- cooling coil around $12^{\circ} \mathrm{C}$, finally supplied to 
radiant panel for indoor air conditioning. Mixed hot water from $\mathrm{CHP}$ and solar thermal system is firstly supplied to absorption chiller as heat source, and then regenerating coil around $70^{\circ} \mathrm{C}$. In system 2 , both chilled water and hot water is used as cascading for improvement of thermal energy efficiency.

Table 2 shows the specifications of system 2 . The target room condition is $26^{\circ} \mathrm{C} 45 \%$. In system 2 , dehumidification amount at pre-cooling coil and dehumidification wheel is determined by the supply dew point. When supply dew point is low and hot water to regenerating coil is not enough, chilled water will be supplied to pre-cooling coil to dehumidify the supply air. Supply air volume is determined by $\mathrm{CO}_{2}$ condensation of each room.

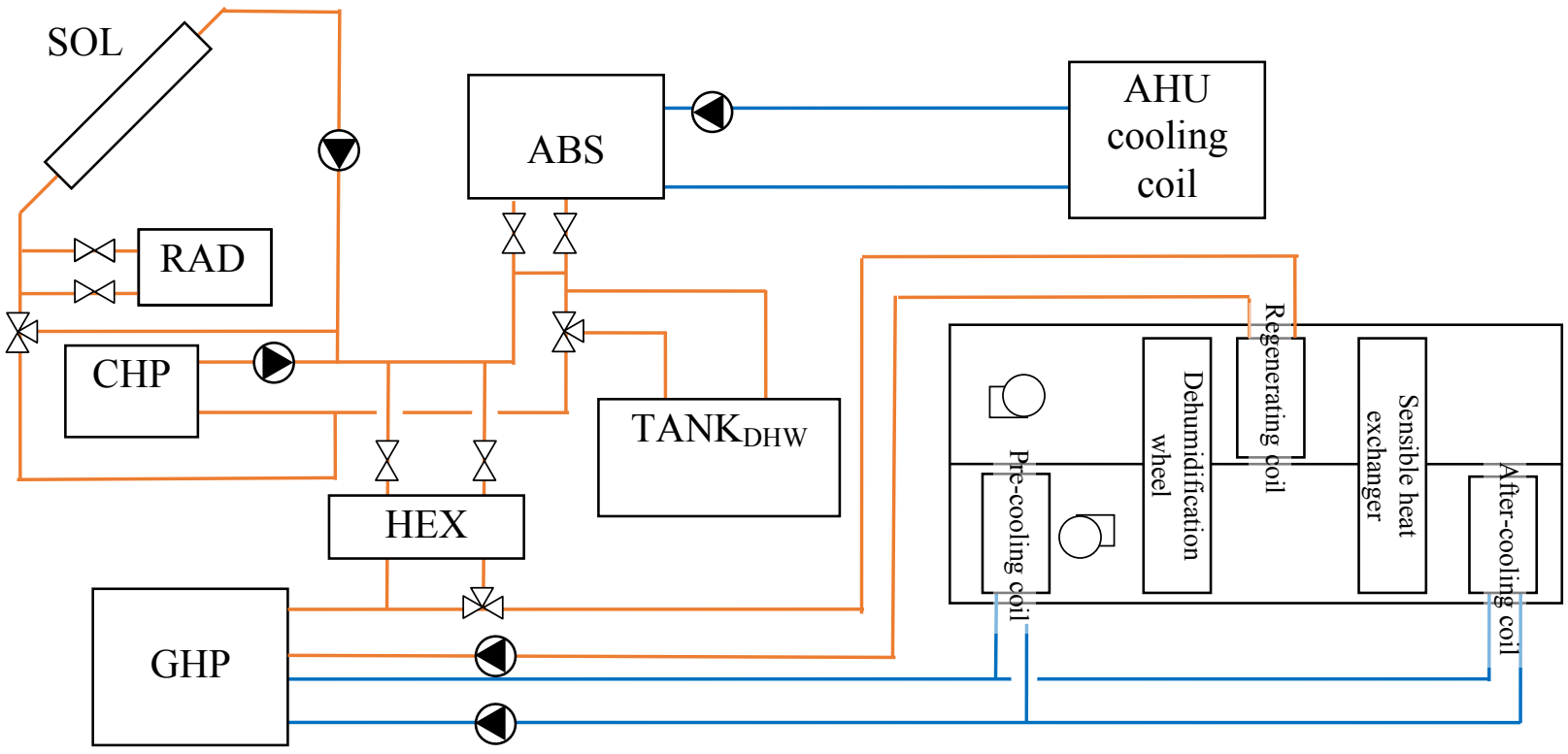

Fig.1 Diagram of System 1

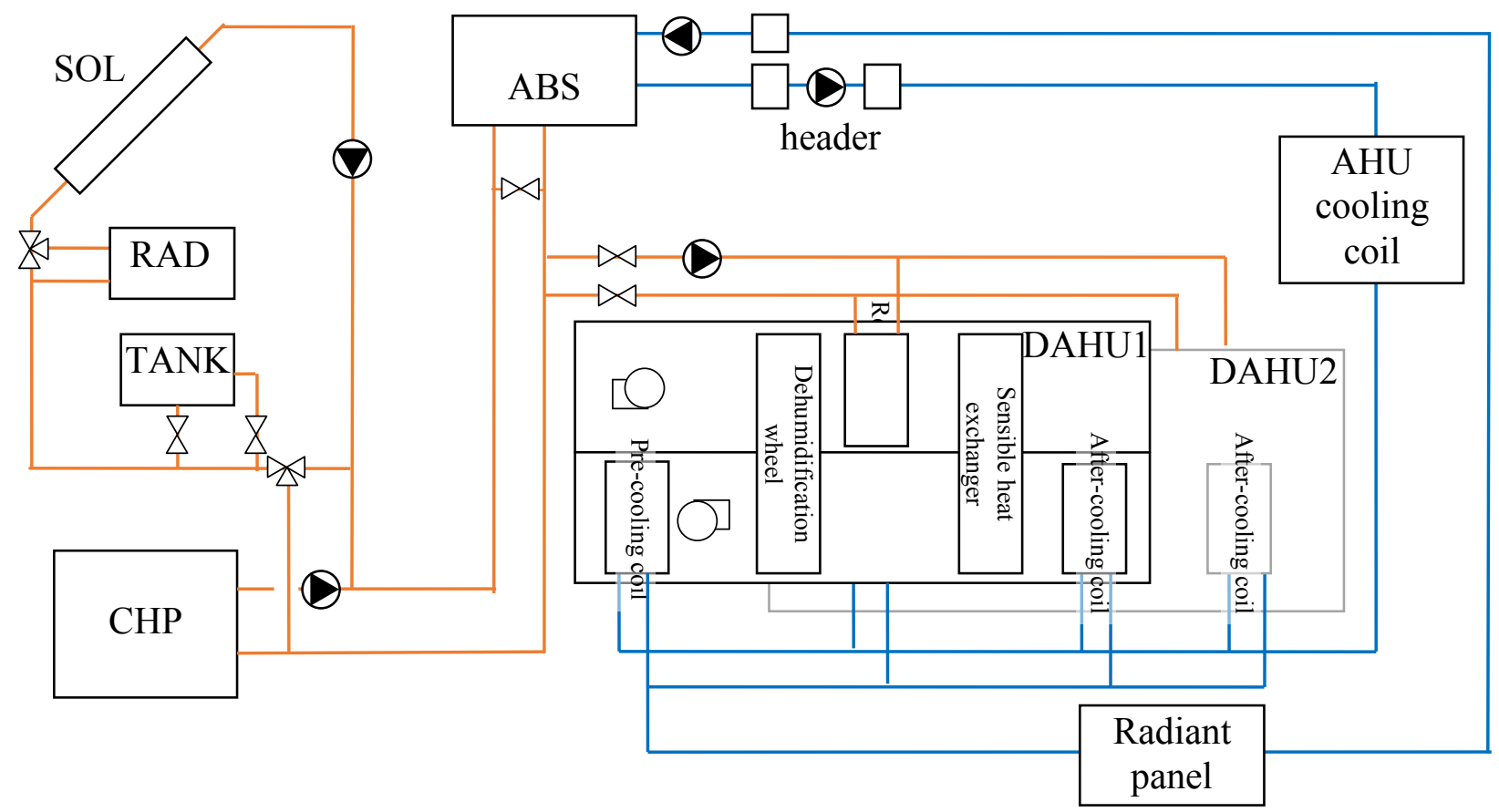

Fig.2 Diagram of system 2 
Table 1. Specifications of system 1

\begin{tabular}{|c|c|c|c|}
\hline Device & $\begin{array}{l}\text { Abbreviati } \\
\text { ons }\end{array}$ & Rated specifications & $\begin{array}{c}\text { Numb } \\
\text { er }\end{array}$ \\
\hline Gas Heat Pump & GHP & $\begin{array}{l}\text { Cooling capacity: } 70 \mathrm{~kW} \text {, Heating capacity: } 80 \mathrm{~kW} \\
\text { Waste hot water capacity: } 30 \mathrm{~kW} \text { (during cooling mode) } \\
\text { Gas consumption: } 67.9 \mathrm{~kW}\end{array}$ & 4 \\
\hline Combined Heat and Power & CHP & $\begin{array}{l}\text { Power: } 35 \mathrm{~kW} \text {, Waste hot water: } 51.5 \mathrm{~kW} \\
\text { Power efficiency: } 34 \% \text { total efficiency : } 84 \% \text { Gas consumption: } 103 \mathrm{~kW}\end{array}$ & 2 \\
\hline $\begin{array}{l}\text { Gas-fired double effect with } \\
\text { hot water singe effect } \\
\text { absorption chiller (ABS) }\end{array}$ & ABS & $\begin{array}{l}\text { Cooling capacity: } 528 \mathrm{~kW} \text {, Heating capacity: } 340 \mathrm{~kW} \\
\text { Hot water input for regenerator: } 159 \mathrm{~kW} \text { Gas consumption: } 32.5 \mathrm{Nm}^{3} / \mathrm{h}\end{array}$ & 1 \\
\hline $\begin{array}{l}\text { Evacuated } \\
\text { collector }\end{array}$ & SOL & $53 \mathrm{~kW}(1.47 \mathrm{~kW} / \mathrm{each})$, Area: $123 \mathrm{~m}^{2}\left(3.41 \mathrm{~m}^{2} / \mathrm{each}\right)$ & 36 \\
\hline Radiator & RAD & $120 \mathrm{~kW}$ & 1 \\
\hline Desiccant air handling unit & DAHU & $\begin{array}{l}\text { Desiccant material: polymer sorbent } \\
\text { Supply air volume: } 14100 \mathrm{~m}^{3} / \mathrm{h} \text { Exhaust air volume: } 9750 \mathrm{~m}^{3} / \mathrm{h} \\
\text { Pre-cooling coil: } 192.6 \mathrm{~kW} \mathrm{After-cooling} \mathrm{coil:} 58.1 \mathrm{~kW} \mathrm{Regenerating} \mathrm{coil:} \\
\text { 101.0kW }\end{array}$ & 1 \\
\hline $\begin{array}{l}\text { Thermal storage tank for } \\
\text { domestic hot water }\end{array}$ & TANK $_{\text {DHW }}$ & $2 \mathrm{~m}^{3}$ & 1 \\
\hline
\end{tabular}

Table 2. Specification of system 2

\begin{tabular}{|c|c|c|c|}
\hline Device & $\begin{array}{c}\text { Abbreviati } \\
\text { ons }\end{array}$ & Rated specifications & $\begin{array}{c}\text { Numb } \\
\text { er }\end{array}$ \\
\hline Combined Heat and Power & CHP & $\begin{array}{l}\text { Power: } 35 \mathrm{~kW} \text {, Waste hot water: } 51.5 \mathrm{~kW} \\
\text { Power efficiency: } 34 \% \text {, total efficiency : } 84 \% \text {, Gas consumption: } 103 \mathrm{~kW}\end{array}$ & 3 \\
\hline $\begin{array}{l}\text { Gas-fired double effect with } \\
\text { hot water singe effect } \\
\text { absorption chiller (ABS) }\end{array}$ & ABS & $\begin{array}{l}\text { Cooling capacity: } 422 \mathrm{~kW} \text {, Heating capacity: } 337 \mathrm{~kW} \\
\text { Hot water input for regenerator: } 174 \mathrm{~kW} \\
\text { Gas consumption: } 31.3 \mathrm{Nm}^{3} / \mathrm{h}\end{array}$ & 1 \\
\hline $\begin{array}{l}\text { Evacuated } \quad \text { type solar } \\
\text { collector }\end{array}$ & SOL & $71 \mathrm{~kW}(1.66 \mathrm{~kW} / \mathrm{each})$, Area: $147 \mathrm{~m}^{2}\left(3.41 \mathrm{~m}^{2} / \mathrm{each}\right)$ & 43 \\
\hline $\begin{array}{l}\text { Thermal storage for solar } \\
\text { thermal system }\end{array}$ & TANK & $4 \mathrm{~m}^{3}$ & 1 \\
\hline Radiator & RAD & $50 \mathrm{~kW}$ & 2 \\
\hline Desiccant air handling unit 1 & DAHU 1 & $\begin{array}{l}\text { Desiccant material: polymer sorbent } \\
\text { Supply air volume: } 11360 \text { Exhaust air volume: } 5685 \\
\text { Pre-cooling coil: } 100.8 \mathrm{~kW} \text { After-cooling coil: } 28.0 \mathrm{~kW} \text { Regenerating coil: } \\
71.4 \mathrm{~kW}\end{array}$ & 1 \\
\hline Desiccant air handling unit 2 & DAHU2 & $\begin{array}{l}\text { Desiccant material: polymer sorbent } \\
\text { Supply air volume: } 10340 \mathrm{~m}^{3} / \mathrm{h} \text {, Exhaust air volume: } 5895 \mathrm{~m}^{3} / \mathrm{h} \\
\begin{array}{l}\text { Pre-cooling coil: } 86 \mathrm{~kW} \text { After-cooling coil: } 27.4 \mathrm{~kW} \text { Regenerating } \\
\text { coil: } 73 \mathrm{~kW}\end{array}\end{array}$ & 1 \\
\hline
\end{tabular}

\section{Measurement results and evaluation}

The data for evaluation is provided by BEMS (Building Energy Management System). For evaluation of DAHU itself, since every one-minute data is fluctuated, the data is transformed into hourly average data. The energy data is measured every one hour, so the original data is used. System 1 started the its operation from July 2015, therefore the data in 2016 is used for analysis. System 2 starts the operation from March 2013. The data in 2015 is used for analysis.

\subsection{Comparison between systems on psychrometric chart}

Fig. 3 shows the air state of system 1 and system 2 on psychrometric chart in August 2016 and August 2015 respectively under the condition that supply air volume is higher than $60 \%$ of rated air volume. Both in system 1 and system 2, supply air absolute humidity is $10 \mathrm{~g} / \mathrm{kg}$ ' However, air condition before dehumidification wheel of the regeneration side is much higher in system 2 because the air volume ratio of system 2 is lower than system 1 , therefore system 2 required higher regeneration temperature. In system 2, when return air volume is not enough for regeneration, outdoor air is mixed in order to keep the minimum air volume. It results in fluctuation of regeneration temperature.

In system 1, since temperature entering dehumidification wheel of process side and supply air temperature is $20^{\circ} \mathrm{C}$, relatively high chilled water can be used for improvement of performance of heat source. 


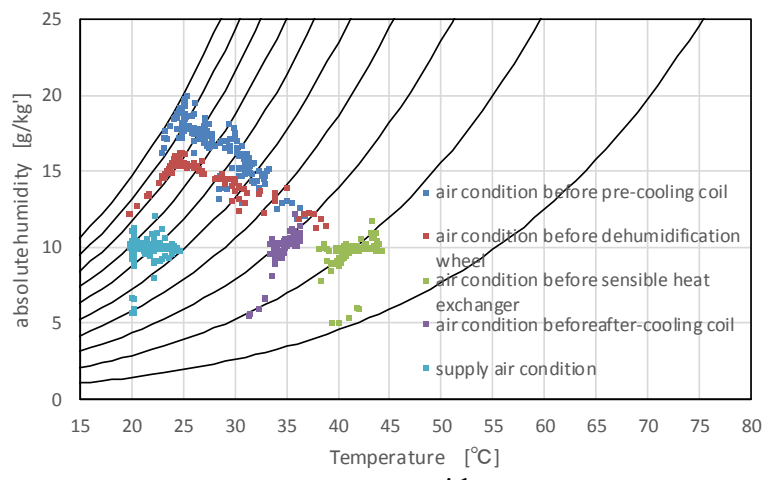

a. process side

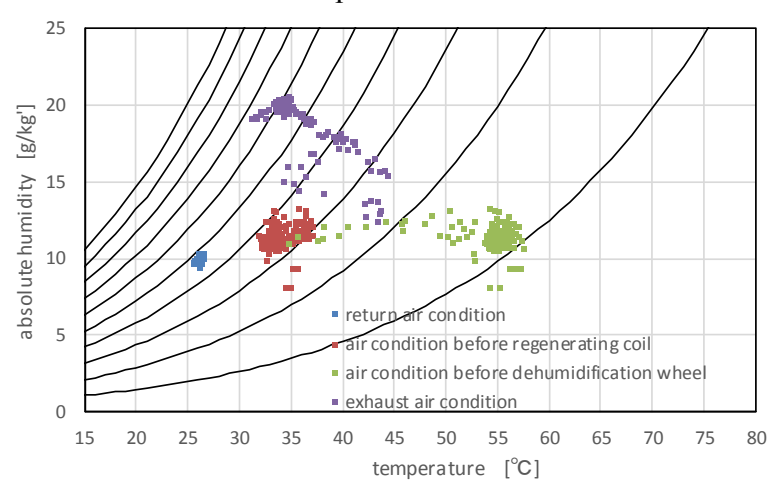

b. regeneration side

(1) System 1

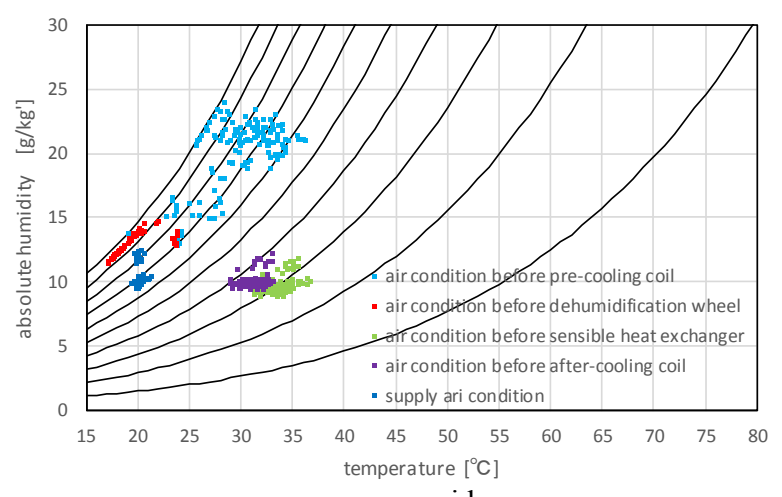

a. process side

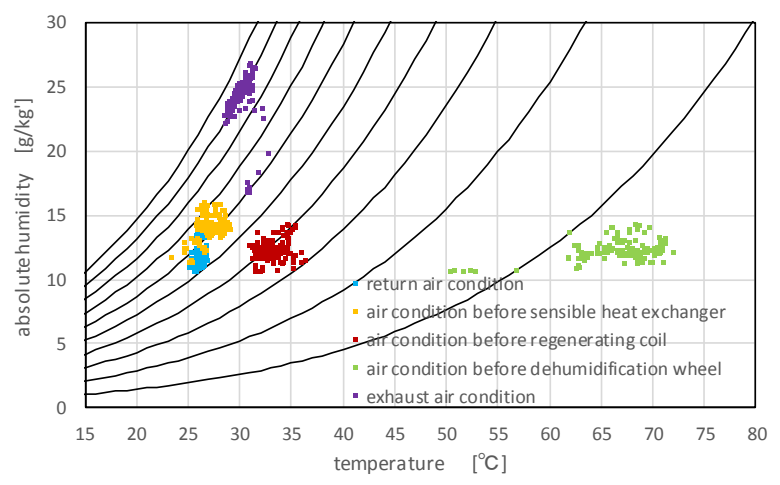

b. regeneration side

(2) System 2

Fig. 3 Air state on pshychrometric chart

\subsection{Relative humidity factor}

Relative humidity factor ( $\left.\eta_{\mathrm{RH}}\right)$ is one of the factors which shows the performance of the desiccant wheels. Relative humidity factor is defined with equation (1).

$$
\eta_{R H}=\left(R H_{\text {pro.pre }}-R H_{\text {pro.dw }}\right) /\left(R H_{\text {pro.pre }}-R H_{\text {re.dw }}\right)
$$

$\mathrm{RH}_{\text {propre }}$ is relative humidity entering dehumidification wheel of process side, $\mathrm{RH}_{\text {pro.dw }}$ is relative humidity passing dehumidification wheel of process side on the same enthalpy line with enthalpy entering dehumidification wheel, $\mathrm{RH}_{\text {re.dw }}$ is relative humidity entering dehumidification of regeneration side.

Fig. 4 shows the relation between relative humidity factor and dehumidification amount per supply air volume depending on air volume ratio. Both in system 1 and system 2, higher relative humidity factor results in greater amount of dehumidification at dehumidification wheel. As equation (1) shows, the lower relative humidity entering dehumidification wheel of regeneration side or/and the higher relative humidity entering dehumidification wheel of process side, the higher relative humditiy factor can be achieved.

System 2 has lower relative humidity factor dehumidified amount at dehuidification wheel than system 1 because air volume ratio is lower. System 1 has clear tendency that higher air volume ratio has higher relative humidity factor.

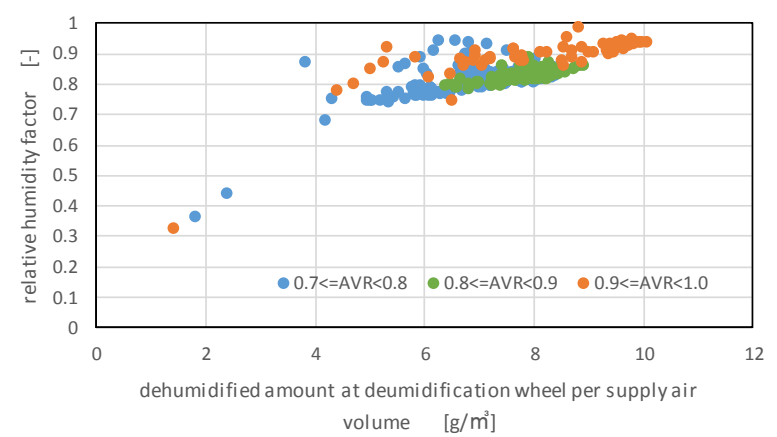

(1) System1

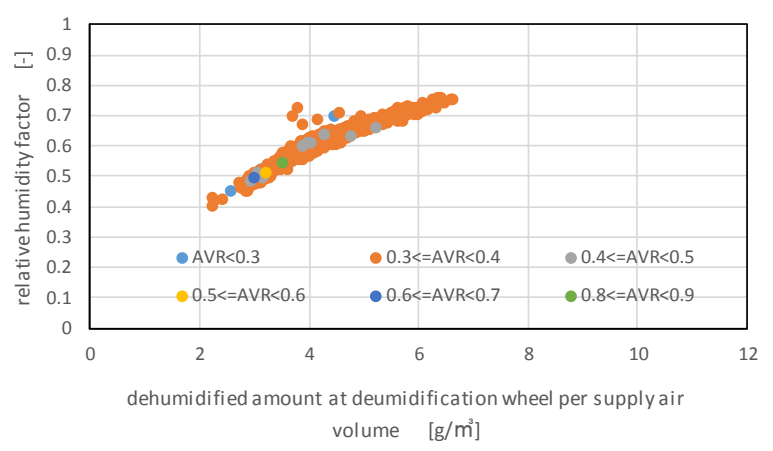

(2) System 2

Fig. 4 relation between relative humidity dactor and dehumidified amount at dehumidification wheel per supply air volume depending on air volume ratio (AVR)

\subsection{Evaluation results}

\footnotetext{
Corresponding author: t-sas@tokyo-gas.co.jp
} 
For evaluation of DAHU itself and DAHS, two different coefficient of performance (hereafter, COP) are proposed. One is desiccant COP $C O P_{d e s}$, and the other is primary-energy-base COP $C O P_{\text {primary }}$ as defined with equation (2) and (3) respectively.

$\mathrm{COP}_{\mathrm{des}}$ is thermal COP which evaluates DAHU itself, and $\mathrm{COP}_{\text {primary }}$ is system COP which evaluates heat source system for DAHS.

$$
C O P_{\text {des }}=Q_{\text {des }} /\left(Q_{\text {pre }}+Q_{\text {after }}+Q_{\text {re }}\right)
$$

$$
\begin{aligned}
& C O P_{\text {primary }} \\
& =\left(Q_{\text {pre }}+Q_{\text {after }}+Q_{r e}\right) /\left(P E_{\text {pre }}+P E_{\text {after }}+P E_{r e}\right)
\end{aligned}
$$

$\mathrm{Q}_{\text {des }}$ is processed air load by DAHU, $\mathrm{Q}_{\text {pre }}$ and $\mathrm{Q}_{\text {after }}$ is chilled water demand to pre-cooling coil and aftercooling coil respectively, $\mathrm{Q}_{\mathrm{re}}$ is hot water demand to regenerating coil. $\mathrm{PE}_{\mathrm{pre}}, \mathrm{PE}_{\mathrm{after}}$, and $\mathrm{PE}_{\mathrm{re}}$ is primary energy consumption of each system to cover the each coil demand.

\subsubsection{Results of $\mathrm{COP}_{\text {des }}$}

Fig. 5 shows the monthly averaged $\mathrm{COP}_{\text {des }}$ for system 1 and system 2. Both in system 1 and system 2, $\mathrm{COP}_{\text {des }}$ in July and August is around 0.7.

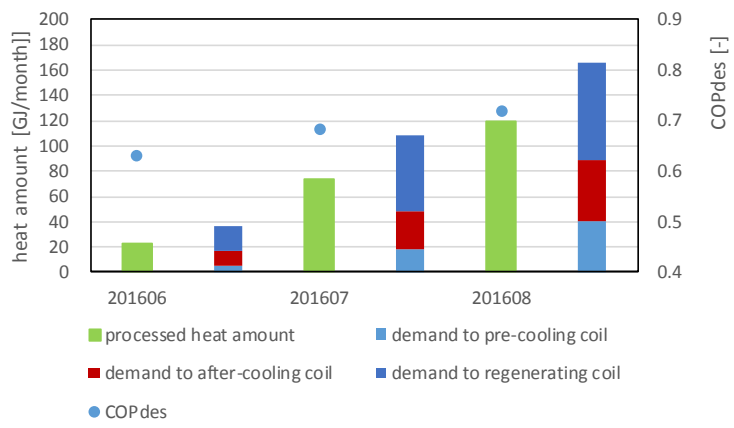

(1) System1

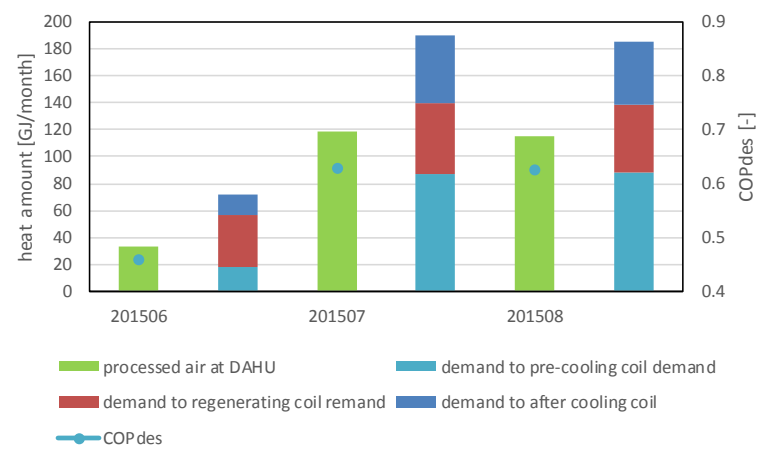

(2) System 2

Fig. 5 Monthly averaged $\mathrm{COP}_{\text {des }}$
Fig. 6 shows thermal energy flow of system 1 in August. All chilled water from GHP is supplied to pre- and after cooling coil. The waste hot water from GHP is supplied to regenerating coil, but when exhaust hot water from GHP is not enough, hot water from CHP will increase the exhaust hot water via heat exchanger. In August, approximately $41 \%$ of hot water from CHP and solar thermal system is distributed to regenerating coil in DAHU. 3\% of hot water from CHP and solar thermal is assumed be heat loss due to circulation and so on.

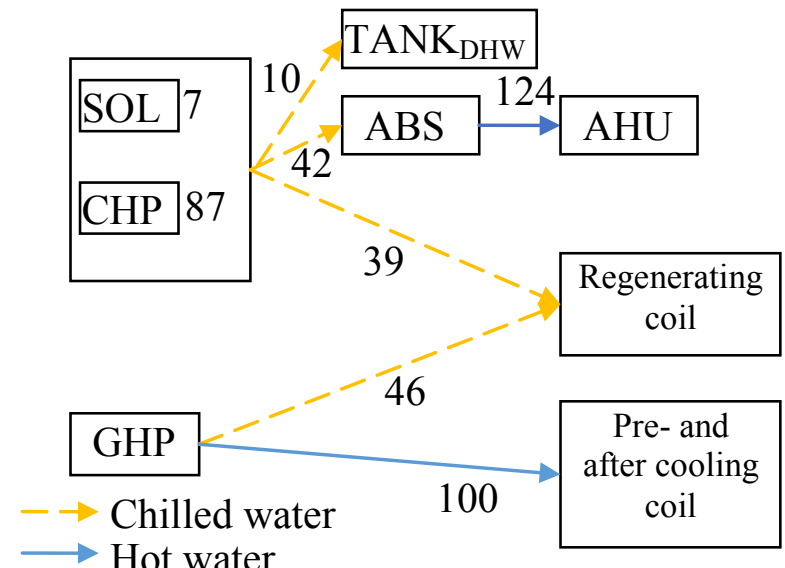

*unit in the above figure is [GJ/month]

Fig.6 Thermal energy frow of system 1 in August

Fig. 7 shows the monthly thermal energy balance of CHP and solar thermal system in system 1 in 2016. In average, $90 \%$ of hot water is used for absorption chiller as heat source, regenerating coil in DAHU, and domestic hot water.

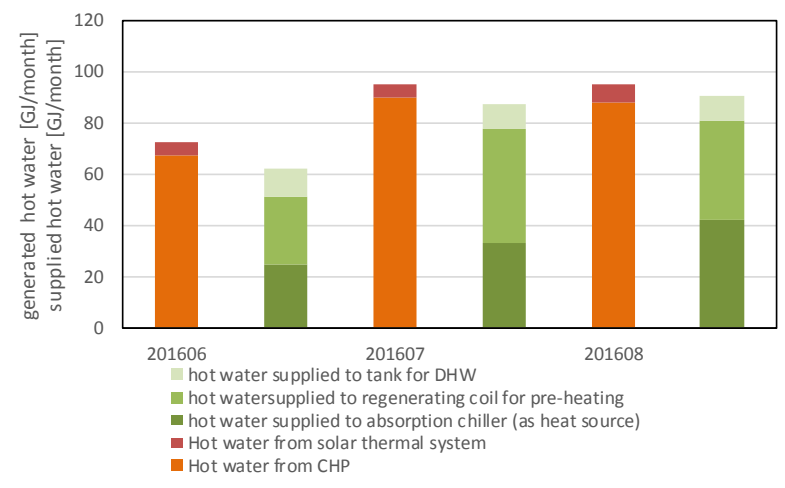

Fig.7 Monthly thermal energy balance of hot water from CHP and solar thermal system in system 1

In system 1, primary energy consumption to cover the demand of DAHU coils is given with equation (4) to equation (7).

$$
\mathrm{PE}_{\text {pre }}+\mathrm{PE}_{\mathrm{after}}=\mathrm{PE}_{\text {ghp }}+\mathrm{PE}_{\text {pump }}
$$

$$
\mathrm{PE}_{\mathrm{re}}=\mathrm{PE}_{\text {re.by GHP }}+\mathrm{PE}_{\text {re by CHP and STS }}
$$




$$
\mathrm{PE}_{\text {re.by GHP }}=0
$$

$$
\mathrm{PE}_{\text {re by CHP and STS }}=\mathrm{PE}_{\mathrm{CHP}+\mathrm{SOL}} \times\left(\mathrm{Q}_{\text {re.hex }} / \mathrm{Q}_{\text {hot. all }}\right)
$$

$\mathrm{PE}_{\mathrm{re}}$ by GHP is primary energy consumption for regenerating coil demand covered by exhaust hot water from GHP. The hot water from GHP is assumed as waste heat, so it is assumed to be zero. $\mathrm{PE}_{\text {ghp }}$ is primary gas consumption of GHP, $\mathrm{PE}_{\text {pump }}$ is electricity consumption of pumps for GHP. PE $\mathrm{E}_{\mathrm{re}}$ by CHP and STS is primary energy consumption for regenerating coil demand covered by $\mathrm{CHP}$ and solar thermal system. $\mathrm{PE}_{\mathrm{CHP}+\mathrm{SOL}}$ is total primary energy consumption including gas consumption of CHP and electricity consumption for pumps. $\mathrm{Q}_{\mathrm{rech}}$ is regenerating coil demand covered by $\mathrm{CHP}$ and solar thermal system through heat exchanger. $\mathrm{Q}_{\text {hotall }}$ is total thermal energy used for absorption chiller and regenerating coil.

In system 1, as shown in Fig. 6, all of pre- and aftercooling demand and part of regenerating coil demand is covered by GHP, therefore gas consumption of GHP and electricity consumption of circulation pump is considered. The rest of the demand to regenerating coil demand by CHP and solar thermal system is provided by distributing the concerned energy based on thermal energy flow proportionally using equation (7).

Fig. 8 shows the energy consumption and $\mathrm{COP}_{\text {primary }}$ of system 1. In June, the COP of GHP is slightly lower than July and August because load factor is low. In July and August, the $\mathrm{COP}_{\text {primary }}$ is high around 1.2.

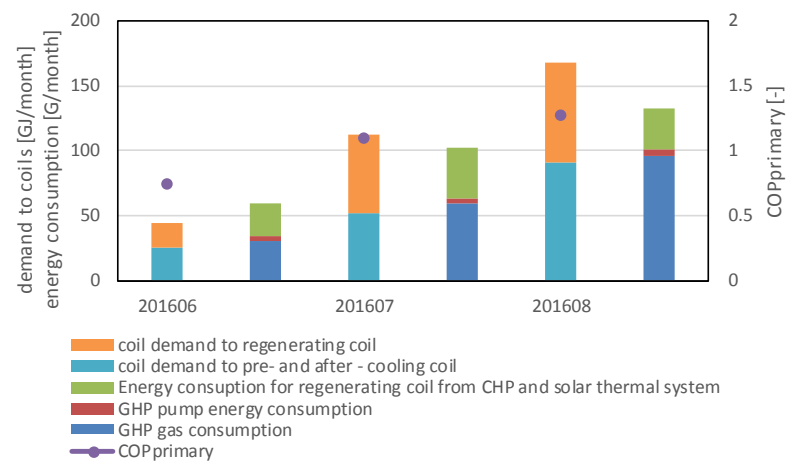

Fig. $8 \mathrm{COP}_{\text {primary }}$ and primary energy consumption of system 1 in 2016

Fig.9 shows the thermal energy flow of system 2 in August. Approximately $36 \%$ of thermal energy from CHP and solar thermal system is supplied to regenerating coil. $73 \%$ of chilled water from absorption chiller is supplied to pre- and after- cooling coil.

Fig. 10 shows the monthly energy balance of heat source in system 2 in 2015. Based on this energy flow, primary energy consumption for DAHS is determined.

In system2, primary energy consumption to cover the demand of DAHU coils is given with equation (8) and equition (9) as follows.

$$
\begin{gathered}
\mathrm{PE}_{\mathrm{pre}}+\mathrm{PE}_{\mathrm{after}}=\mathrm{PE}_{\mathrm{ABS}} \times\left(\mathrm{Q}_{\mathrm{pre}}+\mathrm{Q}_{\mathrm{after}}\right) / \mathrm{Q}_{\mathrm{ABS}} \\
\mathrm{PE}_{\mathrm{re}}=\mathrm{PE}_{\mathrm{CHP}+\mathrm{SOL}} \times \mathrm{Q}_{\mathrm{re}} / \mathrm{Q}_{\mathrm{CGS}+\mathrm{SOL}}
\end{gathered}
$$

$\mathrm{PE}_{\mathrm{ABS}}$ is total primary energy consumption including gas consumption of absorption chiller, and electricity consumption of cooling fan and pump. $\mathrm{Q}_{\mathrm{ABS}}$ is chilled water load. $\mathrm{PE}_{\mathrm{CHP}+\mathrm{SOL}}$ is total primary energy consumption including gas consumption of CHP, exhaust hot water circulation pump, solar thermal circulation pump. $\mathrm{Q}_{\mathrm{CGS}+\mathrm{SOL}}$ is total thermal energy.

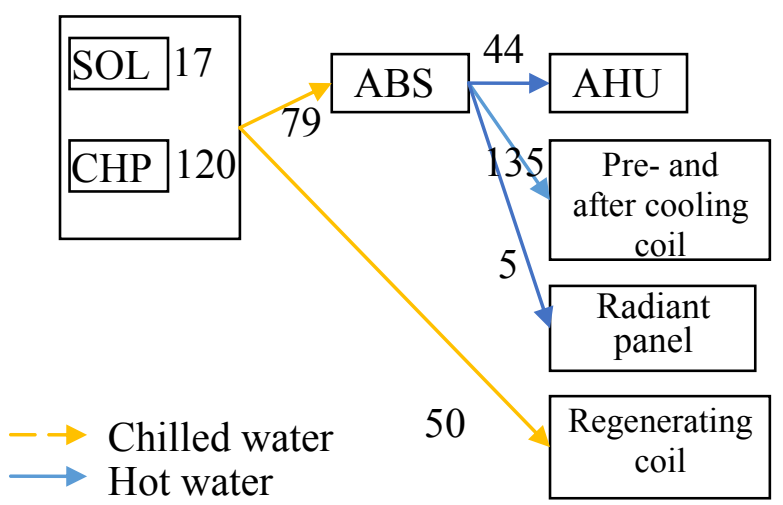

*unit in the above figure is $[\mathrm{GJ} / \mathrm{month}]$ Fig. 9 Thermal energy flow in August

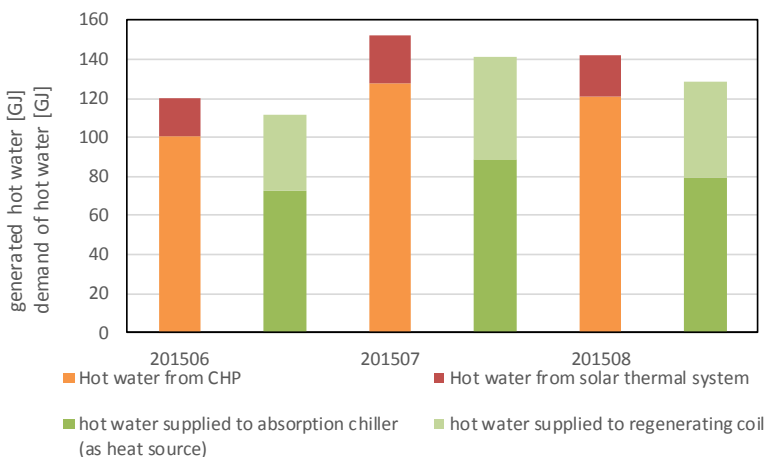

(a) hot water

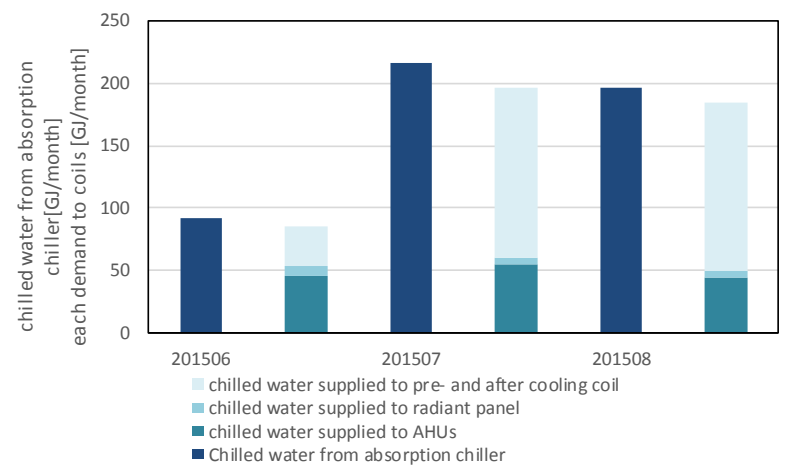

(a) chilled water

Fig. 10 Monthly thermal energy balance of hot water of system

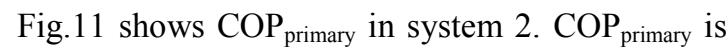
around 1.5 , which is higher than system 1 . In system 2 , hot water from CHP's waste heat is used not only to regenerating coil of DAHU, but also to the absorption chiller as heat source, so the hot water from CHP 
contributes production of both chilled water and hot water to DAHU. On the other hand, in system 1 , hot water from CHP does not contribute the chilled water demand of DAHU. This difference results in higher $\mathrm{COP}_{\text {primary }}$ in system 2 than in system 1.

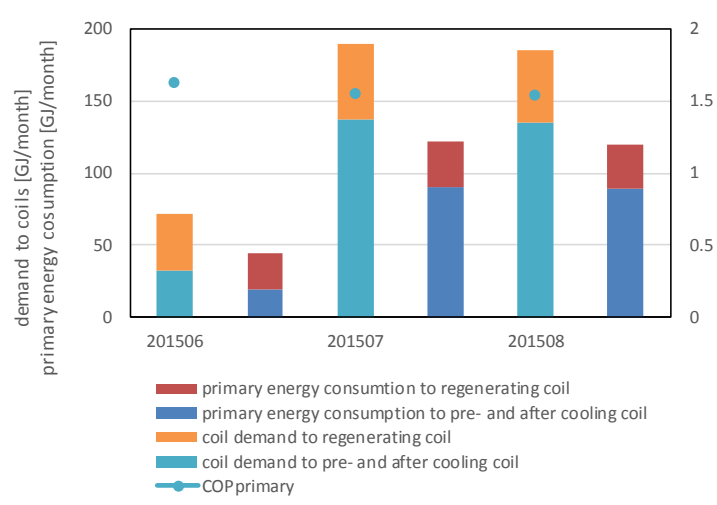

Fig.11 COP $\mathrm{Crimary}_{\text {and }}$ primary energy consumption in system 2 in 2015

\section{Discussion}

According to another paper [1] which conducted measurement analysis of DAHU composed of precooling coil, dehumidification wheel, regenerating coil, sensible heat exchanger and after cooling coil, $\mathrm{COP}_{\text {des }}$ is around 0.7 in July and August in 2013 and 2014. As shown in Fig. 5, systems in this study achieved almost same $\mathrm{COP}_{\text {des }}$ with the reference paper. This value of $\mathrm{COP}_{\text {des }}$ will be good benchmarks for evaluating DAHU with polymer sorbent for other systems.

When evaluating DAHS with heat source including chillers, CHP, solar thermal system and so on, it is necessary to consider the thermal energy flow as shown in Fig. 6 and Fig.9 for especially complex DAHS. The difference of $\mathrm{COP}_{\text {primary }}$ between system 1 and system 2 resulted from system COP of heat source as well as sharing rate of heat source to cover coil demand. Therefore, it is difficult to show typical value of $\mathrm{COP}_{\text {primary }}$, however, this study provided good example of evaluation of DAHS with primary energy base.

\section{Conclusion}

This paper presented actual measurement data and evaluation of various desiccant air handling system including heat source during summer season.

1) High relative humidity factor results in larger amount of dehumidification at dehumidification wheel. Relative humidity factor is mainly determined by air volume ratio and the relative humidity entering dehumidification wheel both process and regeneration side.

2) Coefficient of performance of desiccant air handling unit itself is around 0.7 in summer with polymer sorbent.
3) Coefficient of performance of desiccant air handling system with primary energy base is higher than 1.0 in July and August. The value depends on the coefficient of performance of heat source and the distribution of each heat source.

\section{Appendix}

In this study, the primary energy consumption for waste heat from CHP is given by equation (10).

$$
\mathrm{PE}_{\mathrm{wh}}=\mathrm{PE}_{\mathrm{g} . \mathrm{CHP}}-\mathrm{PE}_{\mathrm{e} . \mathrm{CHP}}
$$

$\mathrm{PE}_{\mathrm{wh}}$ is assumed primary energy consumption for waste heat, $\mathrm{PE}_{\mathrm{g} . \mathrm{CHP}}$ is primary gas consumption of CHP, $\mathrm{PE}_{\mathrm{e} . \mathrm{CHP}}$ is generated power by CHP which is converted to primary energy. Primary energy consumption unit of electricity in Japan is $9.76 \mathrm{MJ} / \mathrm{kWh}$. Primary energy factor for gas is $45 \mathrm{MJ} / \mathrm{Nm}^{3}$.

\section{References}

1. M. Ukai, H. Tanaka, H. Tanaka, M. Okumiya. Energy and Buildings. 172,478-492, 8 (2018) 